\title{
ELEMENTI DEMOGEOGRAFSKEGA RAZVOJA V ZGRADBI MARIBORA
}

\author{
Mirko Pak *
}

\section{IZVLEČEK}

UDK 911.3:312(497.12 Maribor)

Na osnovi analize gibanja sttevila prebivalstva in gospodinjstev v obdobju 1948/91 za mestni teritorij, predmestna in obmestna naselja, so bili opredeljeni procesi demogeografskega razvoja makroregionalnega industrijskega središca Maribora.

\section{ABSTRACT}

UDC 911.3:312(497.12 Maribor)

SOME ELEMENTS OF POPULATION DEVELOPMENT IN MARIBOR

Proceeding from the analysis of changes in the number of population and households on the territory of Maribor - the very city and its inner and outer suburban settlements - in the period 1948 - 91 , we have defined processes of demogeographic development of this macroregional industrial center.

\section{UVOD}

Maribor, za katerega je bila že pred leti ugotovljena gospodarska stagnacija zaradi prometne izoliranosti, kadrovske deficitarnosti ter seveda strukturne neustreznosti mariborskega gospodarstva in కe posebej njegove industrije, doživlja podobne demografske procese kot veliko evropskih mest. Prebivalstvo Maribora se naglo stara, priliv mladih generacij je vse manjši in na pragu 21.stoletja naj bi bilo mariborsko prebivalstvo, ob skromnih priselitvah in ob prenizki fertilnosti, tudi že na pragu demografske smrti. ( Kus , 1989 ) Podobne demografske in gospodarske razvojne znacilnosti veljajo vse bolj tudi za Sirše obmestje v okviru treh občin, Maribor, Pesnica in RuSe ${ }^{\mathbf{1}}$.To mestu $\mathrm{z}$ njegovimi predmestnimi in obmestnimi naselji ne nudi pogojev za bodox̌i ugodnejši demografski razvoj. Tudi raziskave o dnevnem gibanju delovne sile v mariborski občini silijo h takšnim sklepom ( Kokole, 1985 ), saj ne kažejo trendov njihovega zmanjక̌evanja na račun trajnih selitev v Maribor. ( Kus, 1986)

Dosedanja proucevanja demogeografske problematike Maribora so dokaj redka, posvecena predvsem Sirši regiji. Temeljitejša tovrstna కtudija je le magistrska naloga Zorana Kusa , Demografske osnove dolgoročnega prostorskega razvoja Maribora ob prehodu v 21.stolet je, ki obravnava obmoxje velike obđine Maribor v celoti.Vex je sirših regionalnih študij kot rezultat bolj sistematixnega prourevanja Mariborske regije $\mathrm{v}$ preteklih tridesetih letih.Te so izsle $\mathrm{v}$ zbornikih ob geografskem simpoziju o severovzhodni Sloveniji 1972 leta v Geographici Slovenici 2, ob II. slovensko - slovaškem geografskem simpoziju 1975 leta v Geographici Slovenici 7

* Dr, red. univ. prof, Oddelek za geografijo, Filozofska fakulteta, Aškerčeva 12, 61000 Ljubljana, Slovenija 
in ob 11. zborovanju slovenskih geografov v Mariboru 1978 leta v zborniku Mariborsko Podravje.Posebej skromna je bera poleogeografskih studij mestnega prostora, med katera štejemo le raziskovanja socialno - ekonomske strukture mesta in njegovih predelov ( Pak, 1967,1968,1970,1971 in 1974) in industrijskega prebivalstva. ( Pak, 1979,1980)

\section{GIBANJE ŠTEVILA PREBIVALSTVA}

\section{METODOLOGIJA}

Študija obravnava le en demogeografski segment iz Sirokega problemskega sklopa o zgradbi in razvoju mest.Vendar je ta segment, gibanje Stevila prebivalstva, sintetski odsev vseh elementov zgradbe mestnega organizma. Izbor predmeta obravnave je bil povsem pragmaticen, saj je to eden redkih dostopnih virov, ki ob globalnem vrednotenju procesa omogoca tudi prostorsko primer javo znotraj mestnega teritorija in s sirsim obmox̌jem. Prostorsko sirjenje mesta in izginjanje ostre meje med mestom in podeželjem, je zahtevalo obravnavo tistih predmestnih in obmestnih naselij, ki oblikujejo sirši mestni prostor.

Razvoj Stevila prebivalstva na sklenjeno pozidanem mestnem teritoriju ${ }^{2}$ je obravnavan po statisticnih okolisih, za katere so podatki dosegljivi in primerljivi za tri popisna leta , 1971,1981 in 1991 . Analiza je bila opravljena na naslednjih ravneh:

a) po 57 popisnih okolisih ${ }^{3}$,

b) za levi in desni breg Drave,

c) levi breg Drave je bil razdeljen na dva predela:

na ožje mestno središce med Dravo in železniško progo,

- ter na industrijsko Melje vzhodno od tod.

Desni breg Drave je bil razdeljen na tri predele:

- na osrednji del Tabora in Studence,

- Novo vas in Maribor Jug,

- Tezno in Pobrežje z Brezjem.

d) Trije od teh petih predelov so bili dalje razdeljeni na dva manjša predela:

- ožje mestno središce na staro jedro in na ostalo sirše obmox̌je na levem bregu Drave,

- predel Tabora in Studencev je bil razdeljen na oba sestavna dela,

- jugovzhodni del je bil razdeljen na Tezno ter na Pobrežje skupaj z Brezjem.

Tako je bil sklenjeno pozidani mestni teritorij razdeljen na naslednje stevilo enot - $2: 5: 8$. Vsi izbrani predeli na treh ravneh so do neke mere funkcijsko in zgradbeno enotni ter med seboj dokaj ločljivi. Osnovni meji potekatą po Dravi v smeri vzhod-zahod ter po železniški progi v smeri sever - jug in sta bili vsestranski mejnici v razvoju mesta, kakršne v slovenskih mestih težko zasledimo. Drugo so naravne meje ( tezenska terasa ) ali tradicionalne meje mestnih predelov, med Studenci in Taborom, južno proti Novi vasi in Mariboru Jug. Na levem bregu Drave je staro mestno jedro v okviru nekdanjega obzidja in danes načrtovanega obmo‘ja sanacije, podaljsano na vzhodu. 
Izven sklenjeno pozidanega mestnega teritorija so v proučevanje vključena tista naselja, ki jih je zajela intenzivna urbanizacija, predstavljajo spalna naselja v mestu zaposlenega prebivalstva in jih lahko §tejemo že za mestno območe, tudi zaradi njihove neposredne funkcijske povezanosti z mestom.Ta naselja, od katerih so bili deli nekaterih Mariboru najbližjih naselij prikljuðeni ožjemu mestu, so bila razdeljena v dve skupini:

- na 14 predmestnih naselij in ${ }^{4}$

- na 22 obmestnih naselij. . $^{5}$

Analiza gibanja Stevila prebivalstva in gospodinjstev je bila opravljena v glavnem za obdobje $1971 / 91$, za predmestna in obmestna naselja pa tudi za obdobje $1948 / 91$.

\section{DEMOGEOGRAFSKI RAZVOJ $V$ OŽJEM VPLIVNEM OBMOČJU MARIBORA}

Soodvisnost razvitosti Maribora $\mathrm{z}$ razvitostjo njegovega vplivnega obmox̌ja v obsegu občine je izrazita. Gospodarski stagnaciji in v zadnjem casu nazadovanju, je sledil tudi prebivalstveni razvoj. @e Kus ugotavlja , da je v preteklem 25 letnem obdobju rodnost na obmoxju nekdanje velike občine Maribor upadla za $40 \%$, v Sloveniji pa za okrog $30 \%$ in da je priseljevanje v Maribor skromno, komaj okrog 200 oseb letno. Zato je prebivalstvo narašcalo vedno pocasneje , tudi v vecjjih in prometno najbolje dostopnih krajih, predvsem pa je nazadovalo $v$ manjših in v prometno bolj odmaknjenih naseljih. ( Kus, 1989) Na teritoriju občin Maribor, Pesnica in Ruše, je prebivalstvo narašcalo v obdobju 1971/81 \e za $8,1 \%$, v zadnjih desetih letih pa le se za $0,6 \%$. (Pak, 19870)Prebivalstvo na obmoxju sedanje občine Maribor je sicer narašalo v obdobju 1961/71 š hitreje, toda že v naslednjem desetletju je s 7,8\% narašcalo počasneje, v obdobju 1981/91 pa je celo nazadovalo.Tako tudi Kusova trditev, da se je v občini Maribor izoblikovalo obsežno jedro intenzivnega narašcanja števila prebivalstva z Mariborom kot središ̌em ter na Dravskem polju in na sever proti Šentilju, ne drži več povsem. (Kus, 1989) V resnici gre le కe za posamezna, toda največja podeželska naselja v obmestju Maribora in za pas naselij v Dravski dolini na desnem bregu Drave v občini Ruse. Tudi Stevilo stanovanj,ki je najoxitnejßi kazalec urbanizacije in se posebej suburbanizacije, kaže z $8,5 \%$ eno najmanjßih povečanj med slovenskimi občinami.

Primerjava rasti števila prebivalstva $\mathrm{v}$ mestu, predmestnih in obmestnih naselij kaže urbanizacijske trende, ki so bili prakticno vseskozi usmerjeni v najbližja predmestna naselja. Ta so podobno kot obmestna naselja, spalna naselja mariborske delovne sile. Samo prva povojna leta je prebivalstvo Maribora najhitreje narašalo, potem pa je v razvoju vse bolj zaostajalo za predmestnimi naselji. 


\section{Povprečna letna rast števila prebivalstva (v procentih)}

\begin{tabular}{lcrrrr} 
Obmoxje & $1948 / 53$ & $1953 / 61$ & $1961 / 71$ & $1971 / 81$ & \multicolumn{1}{l}{$1981 / 91$} \\
\hline Maribor & 2,6 & 2,1 & 1,7 & 0,9 & $-0,1$ \\
Predmestna naselja & 2,4 & 2,1 & 2,4 & 1,8 & 0,5 \\
Obmestna naselja & 0,5 & 1,7 & 0,7 & 0,8 & 0,1 \\
Skupaj & 1,3 & 2,0 & 1,7 & 1,0 & 0,0
\end{tabular}

\section{Delě̆ prebivalstva v posameznih obmoxjih (v procentih)}

\begin{tabular}{lrrrrrr} 
Obmoxje & 1948 & 1953 & 1961 & 1971 & \multicolumn{1}{c}{1981} & \multicolumn{1}{c}{1991} \\
\hline Maribor & 79,3 & 80,2 & 80,5 & 80,8 & 80,4 & 79,8 \\
Predmestna naselja & 8,5 & 8,6 & 8,6 & 9,2 & 9,8 & 10.3 \\
Obmestna naselja & 12,2 & 11,2 & 10,9 & 10,0 & 9,8 & 9,9 \\
Skupaj & 100,0 & 100,0 & 100,0 & 100,0 & 100,0 & 100,0
\end{tabular}

Slika 1 
Okrog sklenjeno pozidanega mestnega teritorija se je oblikoval obrox urbaniziranih naselij, v katerega so bile usmerjene selitve s podeželja in iz mesta. Predmestna naselja so dosegla višek prebivalstvene rasti s 24,5\% v obdobju 1961/71, Maribor v obdobju 1953 - 61, obmestna naselja pa s $13,5 \%$ v obdobju 1953/61. Moð̌nejگ̌ povojni razvoj gre nedvomno tudi na račn visokega naravnega prirastka prebivalstva na podeželju. Opisanemu gibanju stevila prebivalstva je ob splošnih gospodarskih dejavnikih in ob prebivalstvenih tokovih botrovalo predvsem naslednje: gradnja stanovanjskega naselja Maribor Jug v zadnjih desetih letih, prevrednotenje nekaterih tradicionalno manjvrednih, predvsem delavskih predelov na desnem bregu Drave , kar je sprožilo množǐ̌no individualno gradnjo. Dalje sanacija starega mestnega jedra in nekaterih drugih delov mesta,ki so postali bivalno zelo privlačni, vztrajanje prebivalstva na podeželju ali celo vračanje na podeželje ter seveda drugačno vrednotenje kmetijskega zemljišca, kar je predvsem na najbolj ugodnih ravnih povrکinah $v$ obmestju gradnjo močno zavrlo.Če v glavnem stagnacija , ali silno pocasna rast prebivalstva Maribora zaradi terciarizacije mestnega središca, staranja prebivalstva, skromne organizirane stanovanjske gradnje $\mathrm{v}$ preteklosti in drugo ne presene $\chi_{a}$, pa stagnacija v obmestnih naseljih dejansko nekoliko preseneča. Za drugo urbano in gospodarsko središce R Slovenije so intenzivnejłi tokovi suburbanizacije tukaj pod priðakovanji, క̌e posebej đe primerjamo to rast prebivalstva v $7-15 \mathrm{~km}$ pasu od središa oddaljenih naselij z drugimi podobnimi primeri. Da temu botrujeta gospodarski razvoj mesta samega in njegov industrijski značaj, ni dvoma. Je pa se vrsta drugih omejitvenih dejavnikov od socioekonomske sestave prebivalstva do prometne infrastrukture, nacina življenja in kmetijske usmeritve. Zato je tudi težko pritrditi vedno pogostejšim enačnjem mesta Maribor z obmoxjem mariborske obxine.

\section{RAST ŠTEVIL.A PREBIVALSTVA MARIBORA V OBDOBJU 1971/91}

V Mariboru se je prebivalstvo v zadnjem desetletju zmanjšlo za 0,7\%, ve` kot v celotni obঝi$\mathrm{ni}^{6}$, medtem ko je bilo gibanje $\mathrm{v}$ obeh dvajsetletnih obdobjih 1961/81 in 1971/91 nekoliko ugodnejse v mestu.

Takšen razvoj števila prebivalstva močno odseva tudi v razlikah znotraj mestnega teritorija , kjer se uveljavljajo naslednji osnovni trendi: veða se stevilo statistǐnih okolišev in skupna povrsina z nazadovanjem števila prebivalstva. Takšna obmođja se sklenjeno širijo iz mestnega središca proti obrobju, število prebivalstva se najbolj povečuje $\mathbf{v}$ nekaterih robnih predelih.Prebivalstvo nazaduje vecinoma $v$ predelih kontinuiranega razvoja in కe posebej v primerih mođ̌nejše terciarizacije $\mathrm{v}$ mestnem središcu ter narašca $\mathrm{v}$ redkih predelih pospesene stanovanjske gradnje. Zmanjšujejo ali celo izenacujejo se razlike med predeli s tradicionalno povsem razliðno socialno sestavo prebivalstva, kot je bilo to opredeljeno v socialno-geografskih raziskovanjih pred dvema desetletjema ( Pak, 1970 ).Tipixni " delavski predeli ", ki so za Maribor znacilni , imajo podoben ali celo enak prebivalstveni razvoj kakor " mesčanski " na levem bregu Drave . ( Pak, 1990, 1991 ) V socioekonomski sestavi prebivalstva so se razlike $\mathbf{v}$ večji meri obdržale.Naravno najbolj ugodni " vilski " predeli na severnem obrobju mesta katerim vrednost ponovno raste so prebivalstveno sestavo izboljšli. 


\section{Slika 2}

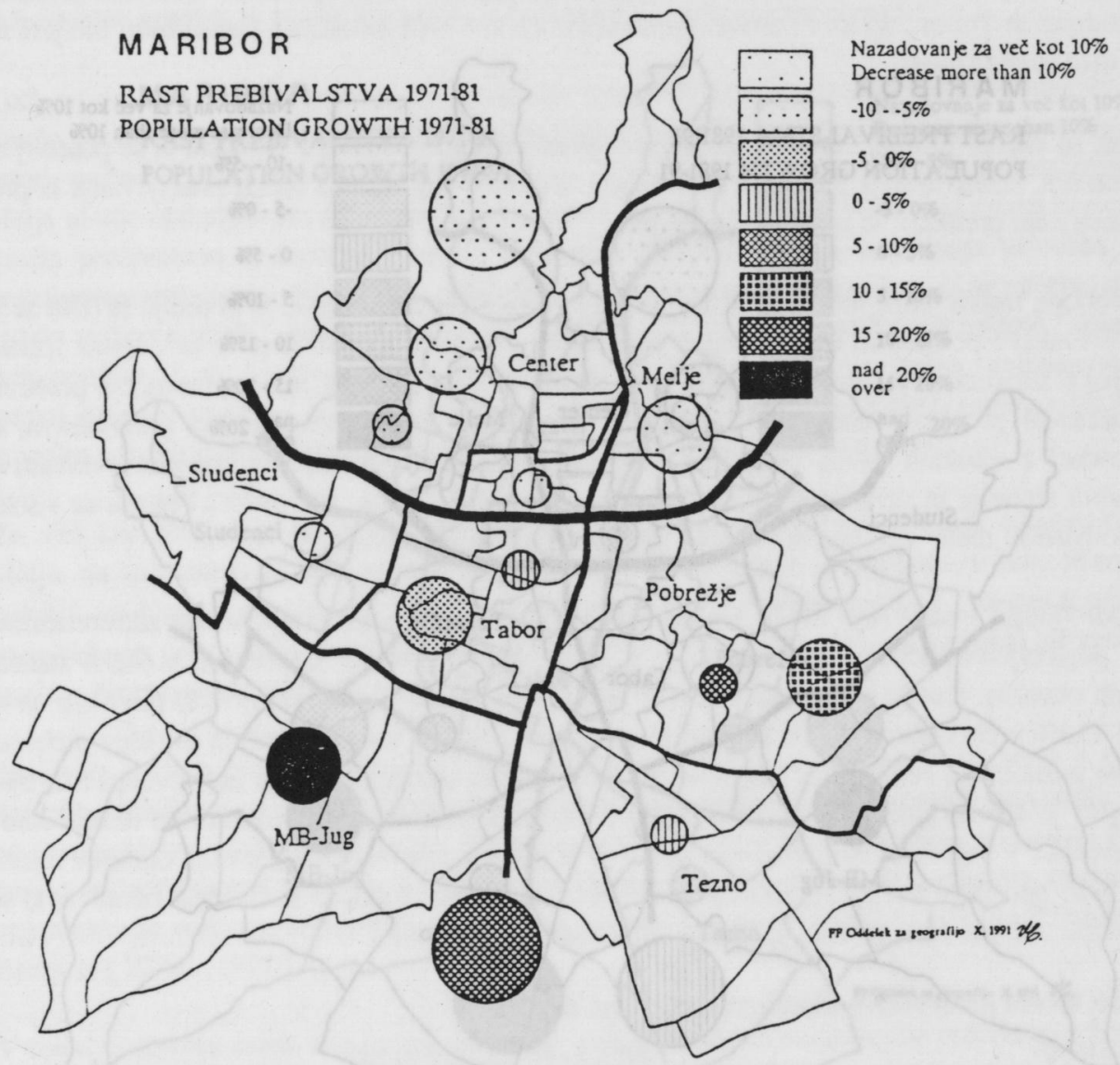


Slika 3

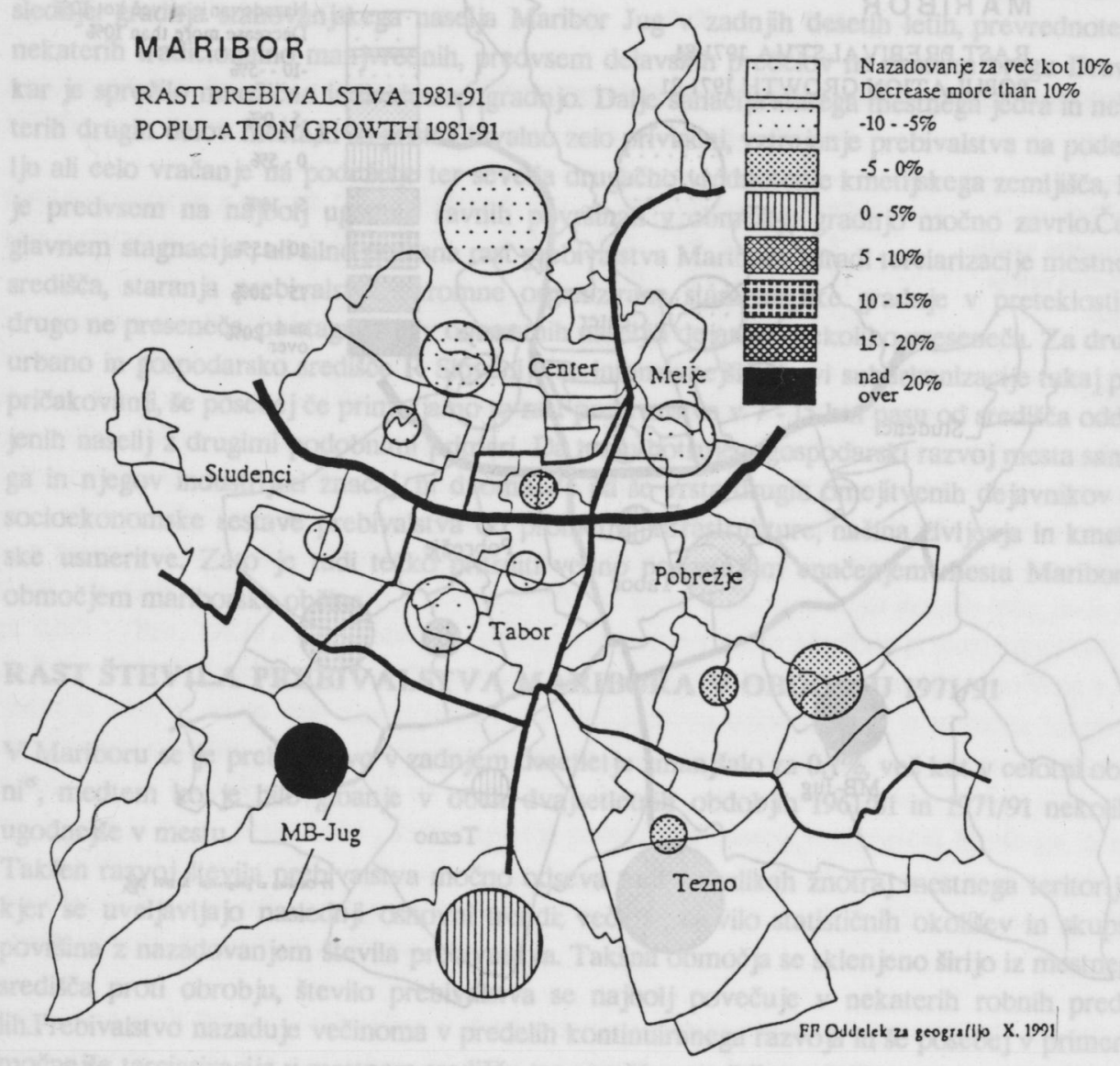




\section{Slika 4}

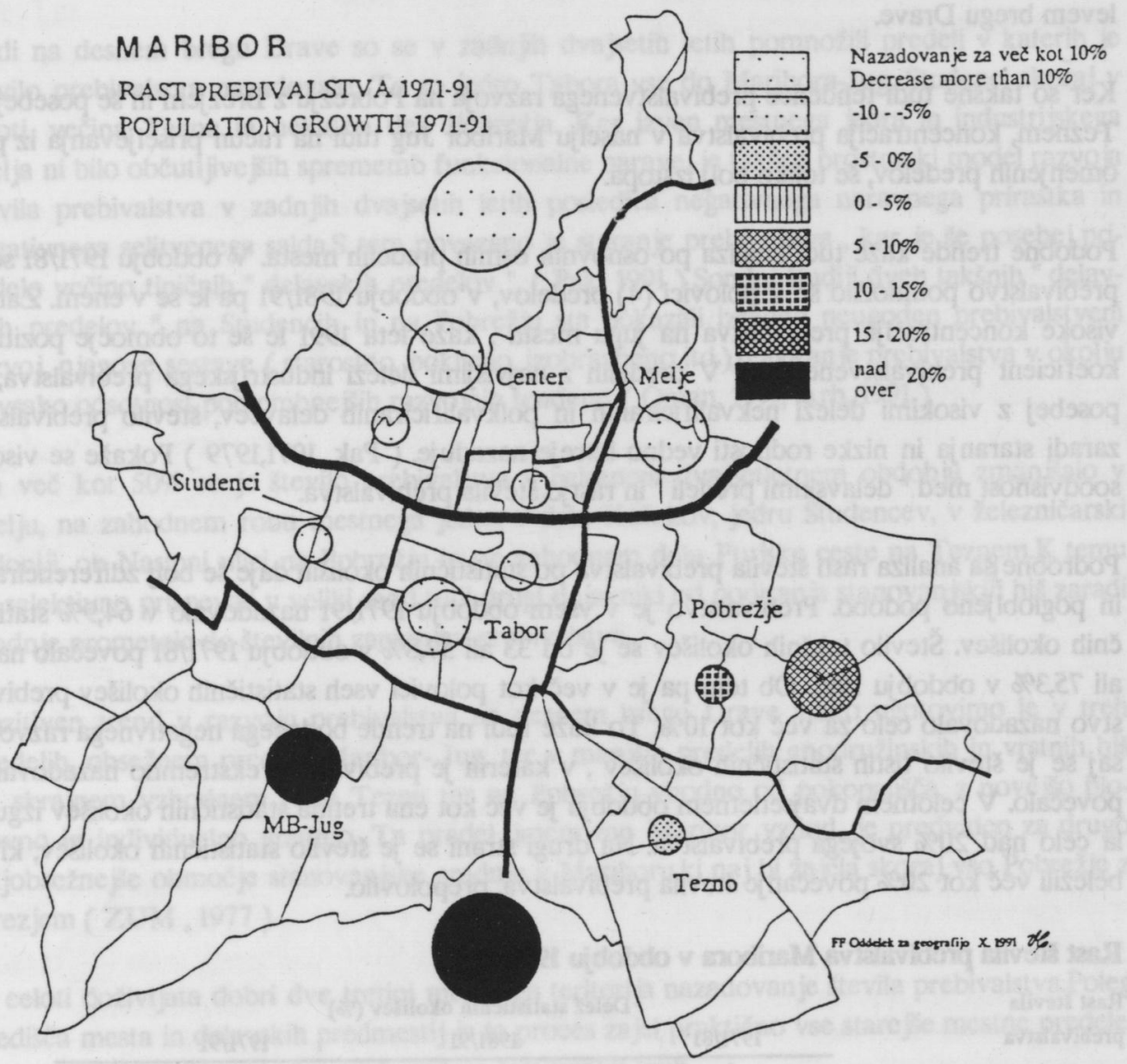


V dvajsetletnem obdobju 1971/91 se je prebivalstvo mesta na obeh bregovih Drave razvijalo zelo razliðno. Na levem bregu se je nazadovanje ves Cas stopnjevalo, na desnem bregu pa je prebivalstvo narašalo spoðetka predvsem zaradi individualnih gradenj, pozneje pa \e posebej zaradi naselja Maribor Jug.Razlika $25 \%$ med obema deloma mesta leta 1971 , se je povecala na $38 \%$ leta 1991. Še v šestdesetih letih prebivalstveno moðno progresivna " delavska predela " Studenci in Tabor, sta se v razvoju prebivalstva že leta 1981 izenacila s Centrom in Meljem na levem bregu Drave.

Ker so takšne tudi tendence prebivalstvenega razvoja na Pobrežju z Brezjem in కe posebej na Teznem, koncentracija prebivalstva $v$ naselju Maribor Jug tudi na racun priseljevanja iz prej omenjenih predelov, se toliko bolj izstopa.

Podobne trende kaže tudi analiza po osnovnih osmih predelih mesta. V obdobju 1971/81 se je prebivalstvo pomnožilo కe $\mathbf{v}$ polovici (4) predelov, $v$ obdobju 1981/91 pa le še v enem. Zaradi visoke koncentracije prebivalstva na jugu mesta, kaže leta 1991 le še to obmoxje pozitivni koeficient prebivalstvene rasti. $\mathbf{V}$ predelih $\mathrm{z}$ najvišjimi deleži industrijskega prebivalstva, š posebej z visokimi deleži nekvalificiranih in polkvalificiranih delavcev, Stevilo prebivalstva zaradi staranja in nizke rodnosti vedno hitreje nazaduje. ( Pak, 1971,1979) Pokaže se visoka soodvisnost med " delavskimi predeli " in rastjo Stevila prebivalstva.

Podrobnejگ̌ analiza rasti క̌tevila prebivalstva po statistǐnih okoliših daje še bolj zdiferencirano in poglobljeno podobo. Prebivalstvo je v vsem obdobju 1971/91 nazadovalo v 64,9\% statisti¿nih okolišev. Število takšnih okolišev se je od 33 ali 57,8\% v obdobju 1971/81 poveðalo na 41 ali $75,3 \%$ v obdobju 1991 . Ob tem pa je $v$ ve kot polovici vseh statistixnih okolisev prebivalstvo nazadovalo celo za vec kot $10 \%$. To kaže tudi na trende bodočega negativnega razvoja, saj se je število tistih statistixnih okolišev, $\mathrm{v}$ katerih je prebivalstvo ekstremno nazadovalo, povečalo. $\mathrm{V}$ celotnem dvajsetletnem obdobju je veð kot ena tretina statistǐ̌nih okolisev izgubila celo nad $20 \%$ svojega prebivalstva. Na drugi strani se je క̌tevilo statistǐnih okolišev, ki so beležili ve`̌ kot $20 \%$ povečanje števila prebivalstva, prepolovilo.

\section{Rast Števila prebivalstva Maribora v obdobju 1971/91}

Rast Stevila
prebivalstva
pod $-10 \%$
$-10,1 \%--5,0 \%$
$-5,0 \%-0,0 \%$
$0,1 \%-5,0 \%$
$5,1 \%-10,0 \%$
$10,1 \%-15,0 \%$
$15,1 \%-20,0 \%$
nad $20 \%$

\begin{tabular}{|c|c|c|c|c|c|}
\hline \multicolumn{4}{|c|}{ Delež statistið̌nih okolišev (\%) } & \multicolumn{2}{|c|}{$1971 / 91$} \\
\hline & kumulativa & & kumulativ & & kumulativa \\
\hline 35,1 & 35,1 & 50,9 & 50,9 & 56,1 & 56,1 \\
\hline 17,4 & 52,5 & 17,4 & 68,3 & 3,5 & 59,6 \\
\hline 5,3 & 57,8 & 7,0 & 75,3 & 5,3 & 64,9 \\
\hline 5,3 & 63,1 & 5,3 & 80,6 & 5,3 & 70,2 \\
\hline 7,0 & 70,1 & 1,7 & 82,3 & 1,7 & 71,9 \\
\hline 5,3 & 75,4 & 7,0 & 89,3 & 5,3 & 77,2 \\
\hline 7,0 & 82,4 & 3,5 & 93,8 & 1,7 & 88,9 \\
\hline 17,4 & 100.0 & 7,0 & 100.0 & 21,0 & 100.0 \\
\hline
\end{tabular}


Na levem bregu Drave se je oblikovalo obsežno sklenjeno obmoxje moxnega nazadovanja Stevila prebivalstva , kar je med drugim tudi posledica spremembe namembnosti prostora, bodisi za potrebe sekundarnega sektorja $\mathrm{v}$ Melju, ali terciarnega $\mathrm{v}$ mestnem središcu.Iz tega sklenjenega obmox̌ja lahko izloximo samo štiri predele $\mathrm{z}$ narašcanjem števila prebivalstva:skrajno zahodno obrobje zaradi blokovne gradnje , Pođehovo in južni del Košakov zaradi individualne gradnje in predel $\mathrm{v}$ središcu $\mathrm{z}$ najnovejگimi sanacijskimi posegi.

Tudi na desnem bregu Drave so se $\mathbf{v}$ zadnjih dvajsetih letih pomnožili predeli $\mathbf{v}$ katerih je Stevilo prebivalstva nazadovalo. To so jedro Tabora vse do Maribora-Jug, Studenci skoraj v celoti, večina Tezna in nekateri deli Pobrežja. Ker izven mestnega jedra in industrijskega Melja ni bilo občutljivejşih sprememb funkcionalne narave, je takšen prostorski model razvoja Stevila prebivalstva $\mathrm{v}$ zadnjih dvajsetih letih posledica negativnega naravnega prirastka in negativnega selitvenega salda.S tem povezano je staranje prebivalstva, kar je se posebej prizadelo večino tipičnih " delavskih predelov ". ( Pak, 1991 ) Sondni కtudiji dveh takšnih " delavskih predelov " na Studencih in na Pobrežju sta pokazali izredno neugoden prebivalstveni razvoj, njegove sestave ( starostno, poklicno, izobrazbeno itd.),reagiranje prebivalstva v okolju in vsako odsotnost pomembnejsih razvojnih tendenc. ( Oman, 1991, Arh, 1991)

Za več kot $50 \%$ se je število prebivalstva $\mathrm{v}$ celotnem dvajsetletnem obdobju zmanjšalo $\mathrm{v}$ Melju, na zahodnem robu mestnega jedra, v delu Košakov, jedru Studencev, v železnicarski koloniji, ob Nasipni ulici na Pobrežju in ob zahodnem delu Ptujske ceste na Teznem.K temu so selektivno prispevali v veliki meri tudi drugi dejavniki od podiranja stanovanjskih hiš zaradi gradnje prometnic do Stevilnih zamenjav prebivalstva.

Pozitiven trend $\mathrm{v}$ razvoju prebivalstva na desnem bregu Drave lahko ugotovimo le $\mathrm{v}$ treh predelih, obsežnem predelu Maribor- Jug, ter $\mathbf{v}$ manjših predelih enodružinskih in vrstnih hiš na skrajnem vzhodnem robu Tezna ter na Pobrežju vhodno od pokopališca, z novejšo blokovno in individualno gradnjo. Ta predel, imenovan Maribor vzhod, je predviden za drugo najobsežnejše obmox̌je stanovanjske gradnje v Mariboru,ki naj bi zajela skoraj vso Pobrežje z Brezjem ( ZUM , 1977 ).

V celoti doživljata dobri dve tretini mestnega teritorija nazadovanje števila prebivalstva.Poleg središ̌a mesta in delavskih predmestij je ta proces zajel praktično vse starejక̌ mestne predele, tudi tiste, ki so bili zgrajeni v petdesetih in sestdesetih letih.

Koeficienti razvoja Števila prebivalstva ( razmerje med deležem rasti v posameznih statistǐ̌nih okoliših in v Mariboru ) kažejo vse najnovejక̌ prostorske spremembe. Število statistǐ̌nih okolisev glede na koeficiente razmerja Stevila prebivalstva: 


\section{Slika 5}

\section{MARIBOR}

RAST PREBIVALSTVA 1971-91 POPULATION GROWTH 1971-91

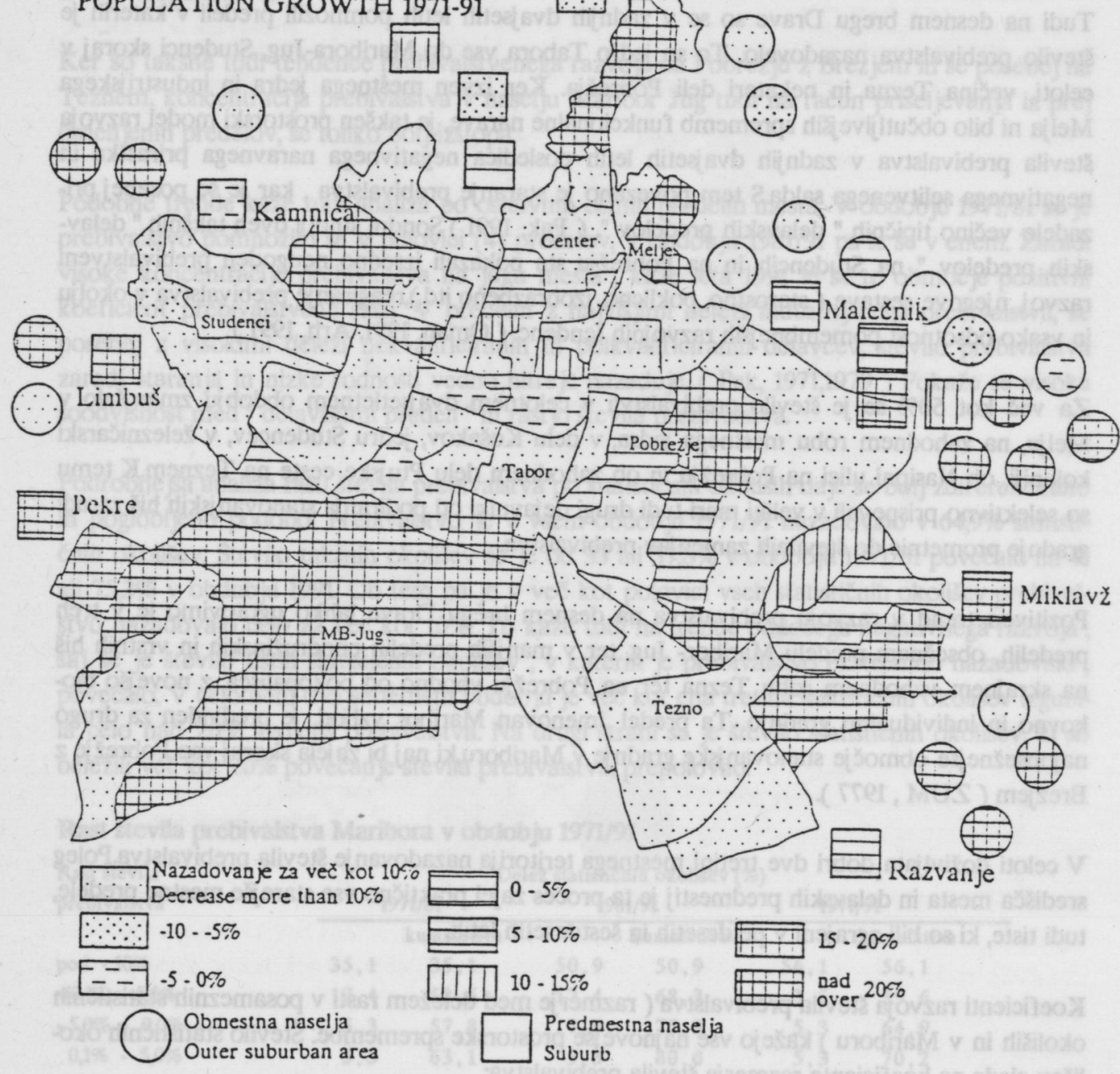




\begin{tabular}{lccc} 
Koeficient & \multicolumn{3}{c}{ Obdobje } \\
$0,16-0,50$ & $1971-81$ & $1981-91$ & $1971-91$ \\
\cline { 2 - 4 } $0,51-0,70$ & 1 & 1 & 6 \\
$0,71-0,90$ & 7 & 4 & 11 \\
$0,91-1,00$ & 25 & 26 & 19 \\
$1,01-1,10$ & 7 & 12 & 5 \\
$1,11-1,20$ & 5 & 4 & 3 \\
nad 1,20 & 4 & 6 & 6 \\
skupaj & 8 & 4 & 7 \\
& 57 & 57 & 57
\end{tabular}

Vidni so doslej omenjeni splošni trendi: zmanjševanje razlik med posameznimi mestnimi predeli, večanje deleža statistǐnih okolišev s koeficientom pod 1 in povečje se pestrost, ki v zadnjem obdobju sledi radialnemu Sirjenju predelov s podpovprečno rastjo, ali celo nazadovanju Števila prebivalstva.

V obdobju 1971 - 81 je imelo podpovprečno rast Stevila prebivalstva 70,2\% statističnih okolisev, v obdobju 1981 - 91 pa že $75,4 \%$.Ti so v prvem obdobju sklenjeno zajemali vso središce mesta na levem bregu Drave in le 3 od 21 statisticnih okolisev na njegovem obrobju je imelo nadpovpreð̌no rast števila prebivalstva.V zadnjem desetletju je bilo tukaj takŠnih statistǐnih okolišev 5 , in $v$ vseh so bile opravljene znatne sanacije. Ker pa se je tudi v nekaterih predelih na severnem obrobju rast prebivalstva približalo povprecju, lahko govorimo o pozitivni povezavi med veðjo bivalno privlacnost jo mestnega prostora in rast jo prebivalstva.

Drugaxni ali celo obratni so bili trendi rasti prebivalstva na desnem bregu Drave, kjer je pozitivni koeficient $\mathrm{v}$ obdobju 1971 - 81 imelo celo 14 od 36 statisticnih okolišev in $9 \mathrm{v}$ obdobju 1981 - 91 .Samo od 6 na 7 pa se je tudi povečalo število statisticnih okolišev tik pod povprečkom.Predeli s podpovprecno rastjo števila prebivalstva se sirijo proti obrobju, prihaja pa tudi do vex̌je polarizacije.Primerjava statističnih okolišev, ki so med obema obdobjema prešli $\mathbf{v}$ visji ali nižji razred, ali so ostali $\mathrm{v}$ istem razredu glede na koeficient rasti števila prebivalstva pokaže $9 \mathrm{v}$ istem razredu, $13 \mathrm{v}$ nižjem in kar $14 \mathrm{v}$ viSjem.

Nekoliko ugodnejši razvoj s podobnimi kvantitativnimi in prostorskimi tendencami doživljajo tudi gospodinjstva. Njihovo stevilo se je v obdobju 1971/91 povecalo za 17,7\%, toda med letoma 1981/91 je le se stagniralo. Kar v 59,6\% statistiennih okolišev je tudi stevilo gospodinjstev nazadovalo, med letoma $1971 / 81$ v 40,3\% in v obdobju 1981/91 kar v 73,6\%. Sicer pa je v vseh treh obdobjih okrog $75 \%$ statistixnih okolisev izkazovalo podpovprěno gibanje števila gospodinjstev, podobno kot velja za Število prebivalcev.

Podobno kot drugod, se je tudi v Mariboru stevilo članov gospodinjstev zmanjకalo od 2,9 na 2,75 leta 1981 in na 2,67 leta 1991. Zmanjłalo se je v vseh osmih predelih Maribora, analiza po 


\section{Slika 6}

\section{MARIBOR}

RAST ŠTEVILA PREBIVALSTVA 1971/1981 POPULATION GROWTH 1971/1981

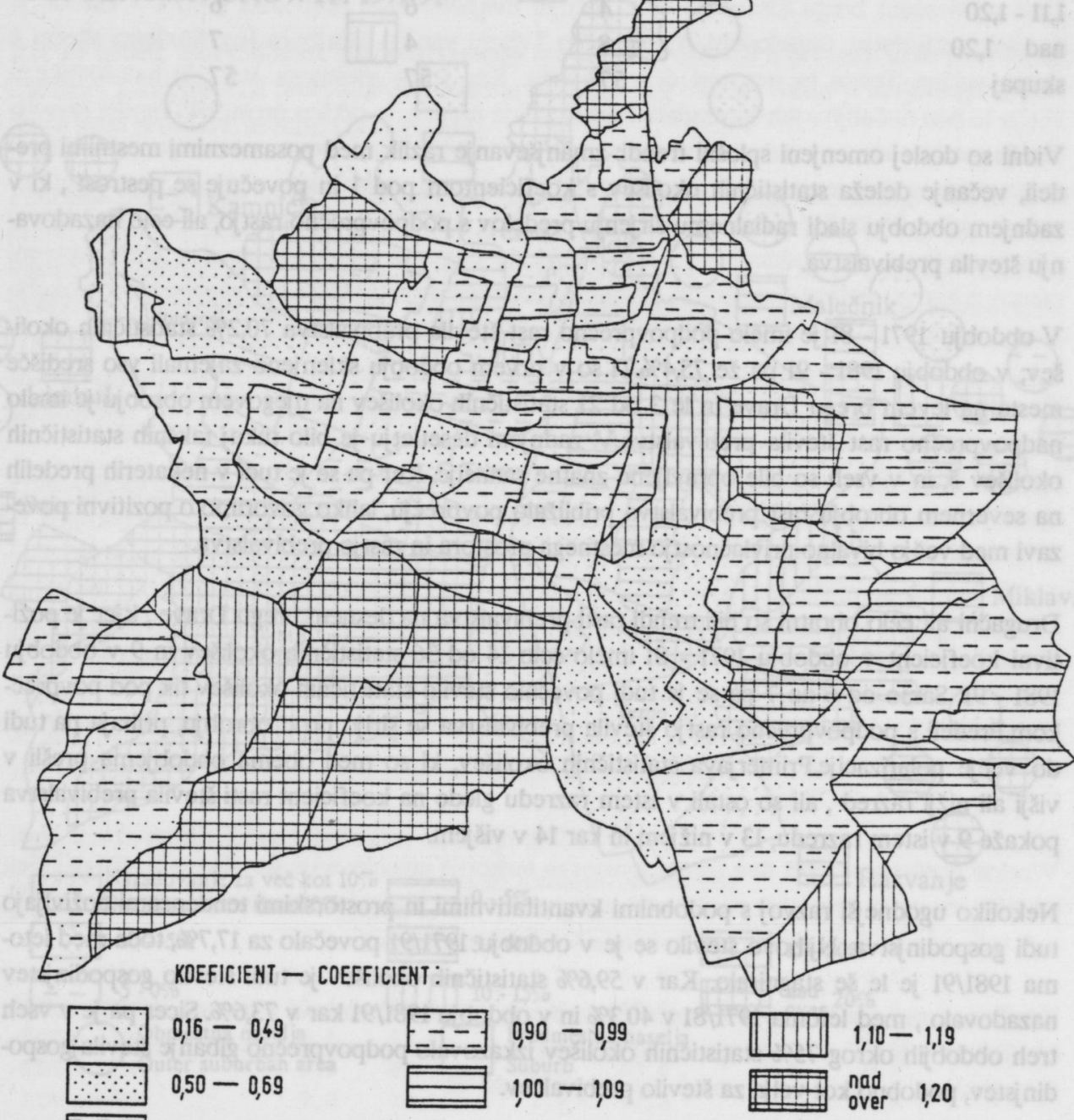

$0,0,80-0$ 
Slika 7

\section{MARIBOR}

RAST ŠTEVILA PREBIVALSTVA 1981/1991

POPULATION GROWTH 1981/1991
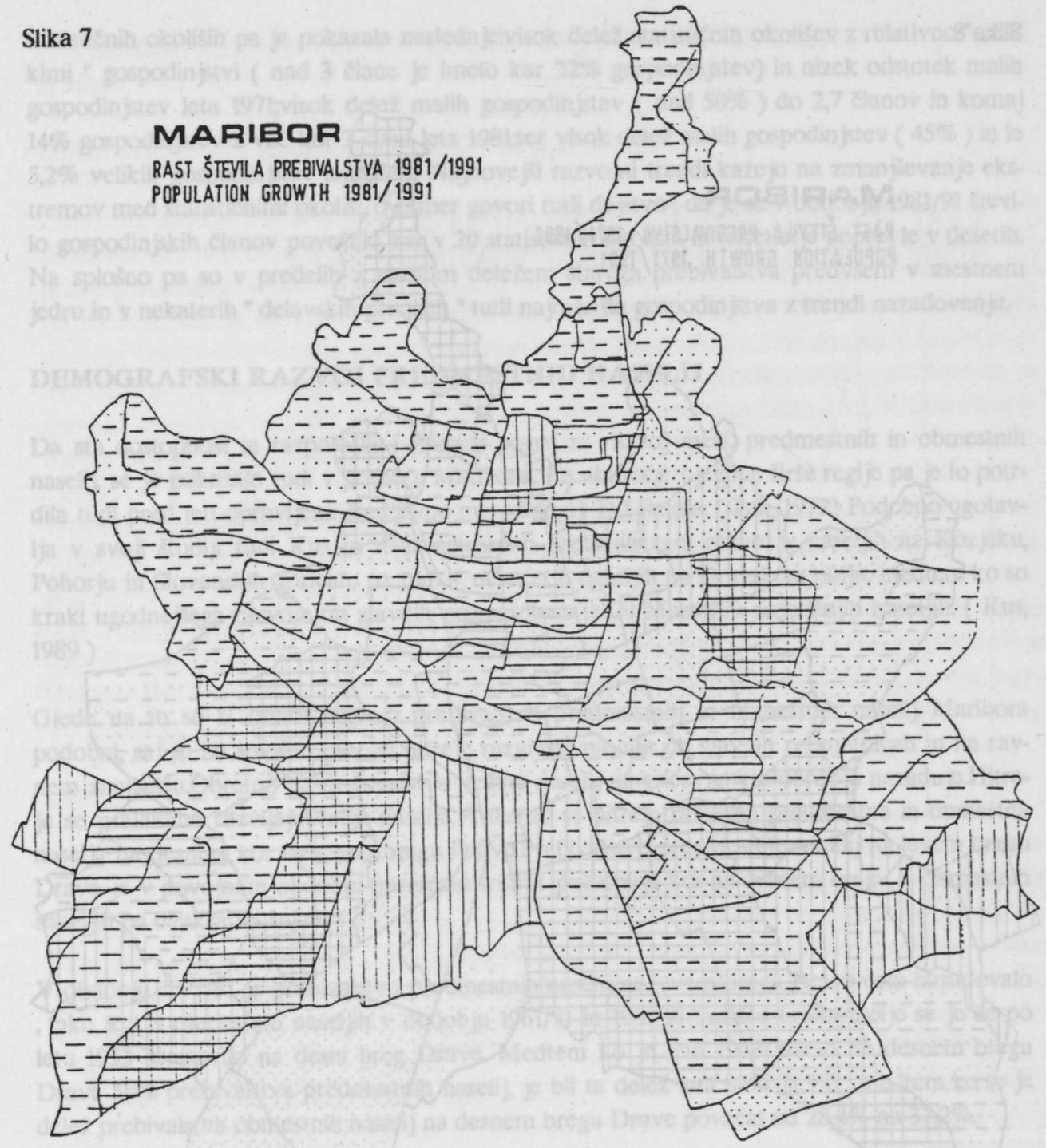

KOEFICIENT - COEFFICIENT:
$\therefore \quad 0,16-0,49$
$\Xi 1,00-1,09$
$0,50-0,69$
II $1,10-119$
E- $0,70-0,89$
nad
over
$=-0,90-0,99$ 
Slika 8

\section{MARIBOR}

RAST ŠTEYILA PREBIYALSTVA 1971/1991 POPULATION GROWTH 1971/1991

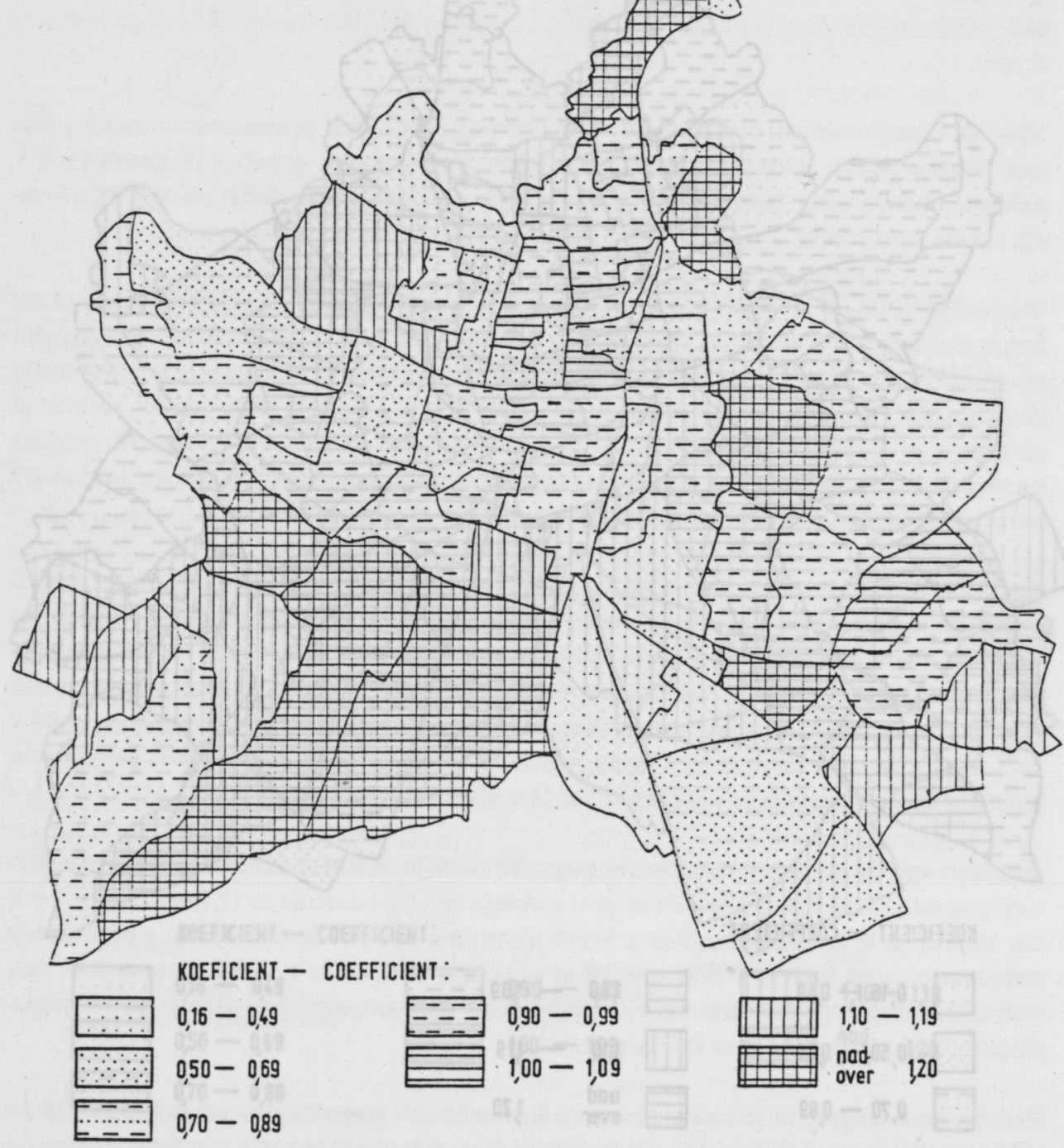


statistǐ̌nih okoliših pa je pokazala naslednje:visok delež statistiðnih okolišev z relativno " velikimi " gospodinjstvi ( nad 3 clane je imelo kar 32\% gospodinjstev) in nizek odstotek malih gospodinjstev leta 1971;visok delež malih gospodinjstev ( nad 50\%) do 2,7 clanov in komaj $14 \%$ gospodinjstev z vex kot 3 clani leta 1981;ter visok delež malih gospodinjstev ( $45 \%$ ) in le $5,2 \%$ velikih gospodinjstev leta 1991. Najnovejši razvojni trendi kažejo na zmanjß̌evanje ekstremov med statistǐnimi okolisi, o cemer govori tudi dejstvo, da je se v obdobju 1981/91 Stevilo gospodinjskih članov povečalo kar v 20 statističnih okoliših in desetletje poprej le v desetih. $\mathrm{Na}$ splošno pa so $\mathrm{v}$ predelih $\mathrm{z}$ visokim deležem starega prebivalstva predvsem $\mathrm{v}$ mestnem jedru in v nekaterih " delavskih predelih " tudi najmanjæa gospodinjstva $\mathrm{z}$ trendi nazadovanja.

\section{DEMOGRAFSKI RAZVOJ PREDMESTNIH NASELIJ}

Da sta dostopnost in razpoložljivi prostor pogoj za razvoj mest, predmestnih in obmestnih naselij, se je pokazalo tudi v primeru Maribora. Za obmox̌je njegove Sirše regije pa je to potrdila tudi pred leti opravljena studija po metodologiji D.J.Bogua. ( Pak, 1972) Podobno ugotavlja v svoji Studiji tudi Kus in sicer neugoden prebivalstveni razvoj v naseljih na Kozjaku, Pohorju in Slovenskih goricah, pa tudi v nekaterih naseljih na Dravskem polju, medtem ko so kraki ugodnejšega razvoja ob glavnih prometnicah ter v Mariboru najbližnjih naseljih. ( Kus, 1989)

Glede na to so si trendi razvoja prebivalstva predmestnih in obmestnih naselij Maribora podobni, saj se na splošno mnogo hitreje razvijajo naselja ob glavnih prometnicah in na ravnem zemljišu.Obratno pa prebivalstvo vecine naselij na gricevnatem obrobju nazaduje.Hitreje se praviloma razvijajo večja naselja. Tako so se hitreje razvijala predmestna in obmestna naselja na desnem kot na levem bregu Drave.Prebivalstvo predmestnih naselij na levem bregu Drave je $v$ povojnem obdobju narašalo trikrat počasneje kot na desnem bregu, v obmestnih naseljih pa dvakrat hitreje.

V obdobju 1971/81 je prebivalstvo predmestnih naselij na levem bregu Drave celo nazadovalo , tako kot v obmestnih naseljih v obdobju 1961/71 in 1981/91.Težišce urbanizacije se je že po letu 1953 prestavilo na desni breg Drave. Medtem ko je leta 1948 živelo na desnem bregu Drave $58 \%$ prebivalstva predmestnih naselij, je bil ta delež leta $199171,3 \%$, medtem ko se je delež prebivalst va obmestnih naselij na desnem bregu Drave povečal od $28,4 \%$ na $37,2 \%$.

V kolikor predmestna naselja, glede na njihov položaj, združimo v tri skupine, na vzhodno na Dravskem polju in pod južnim robom Slovenskih goric, na zahodno v Dravski dolini ter na severno na poboxjih Slovenskih goric, dobimo naslednje razvojne trende:vse do leta 1971 so najhitreje rastla predmestna naselja na prometno in prostorsko najbolj ugodnem vzhodnem obrobju, po tem letu pa naselja v Dravski dolini.Mnogo počasnejsi pa je bil razvoj prebivalstva predmestnih naselij na severnem obrobju mesta. Ta beležijo $v$ dvajsetletnem obdobju 1971/91 celo nazadovanje števila prebivalstva na racun obdobja 1971/81. Najhitreje je prebival- 
Slika 9

RAST PREBIVALSTVA V OBMESTNIH NASELJIH

POPULATION GROWTH IN OTHER SUBURBAN AREA

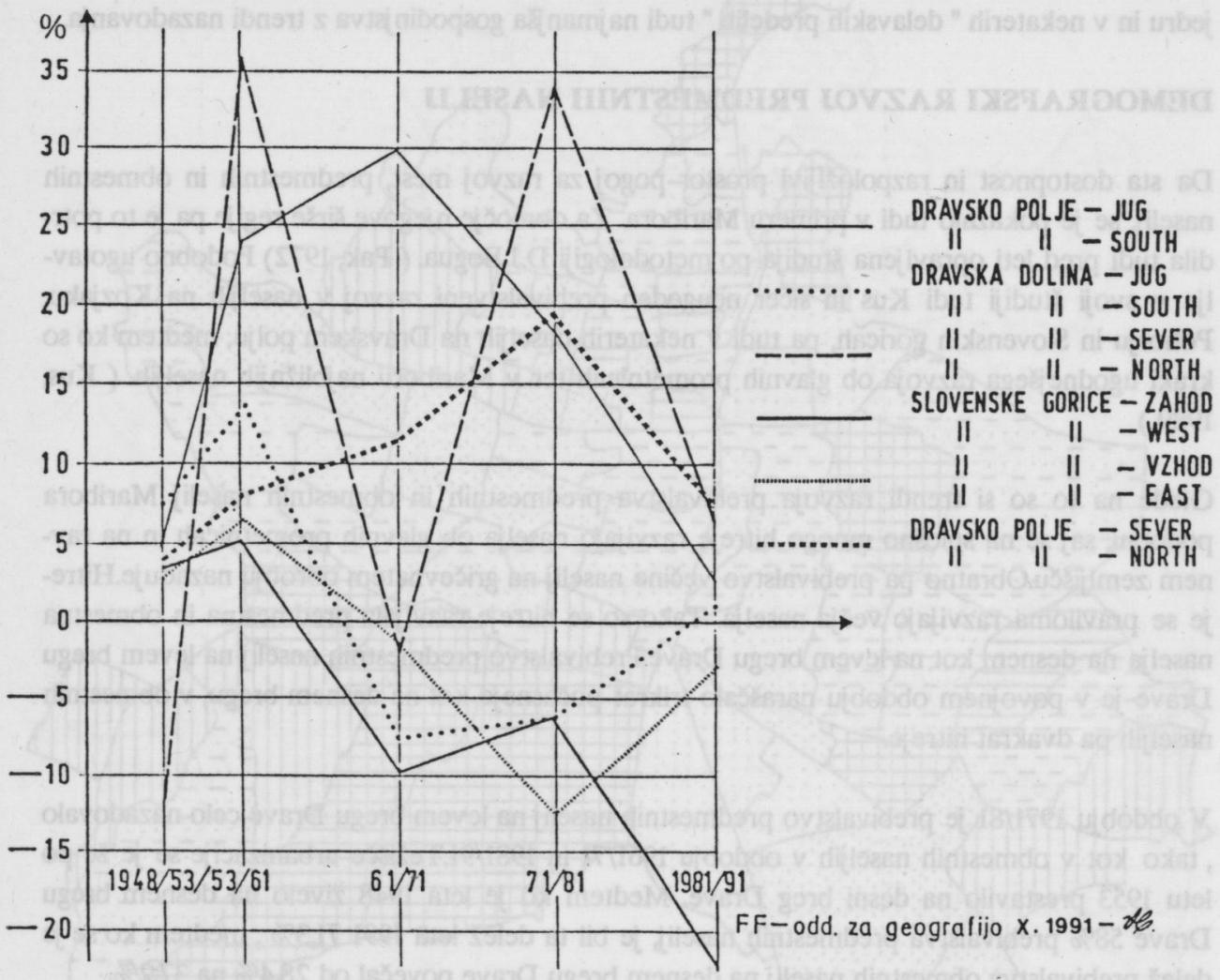


stvo narašcalo v največjih centralnih in izrazito imigracijskih naseljih Dogose, Miklavž, Limbu§ in Pekre.

\section{DEMOGRAFSKI RAZVOJ OBMESTNIH NASELIJ}

Obmestna naselja , $\mathbf{v}$ katerih je prebivalstvo narašalo približno dvakrat počasneje kot $\mathbf{v}$ predmestnih , smo uvrstili v Sest skupin: tista na vzhodnem obrobju mesta na Dravskem polju, pod jugovzhodnim robom Slovenskih goric, na severnem in na južnem bregu v Dravski dolini ter na zahodnih in na vzhodnih obronkih Slovenskih goric. Po letu 1969 je prebivalstvo obmestnih naselij $\mathrm{v}$ Slovenskih goricah $\mathrm{v}$ glavnem nazadovalo in kar 7 od skupno 9 naselij je po letu 1971 prebivalstvo izgubljalo.Dostopnost je tukaj najbolj problematicna, primankuje za gradnjo primernih zemljiš in ob razpršeni poselitvi je problematǐna tudi infrastrukturna opremljenost. $\mathrm{V}$ ta naselja je priseljevanje najmanjse.

Izmed ostalih skupin obmestnih naselij kažejo konstantno občutnejše povecanje stevila prebivalstva le tista na Dravskem polju ter deloma na levem bregu Drave v Dravski dolini. Razvojni trendi so pri posameznih skupinah naselij iz obdobja $v$ obdobje razliěni in točno eno tretino vseh obdobnih gibanj prebivalstva je negativnih.Na skromen razvoj obmestnih naselij kaže tudi to, da je $\mathrm{v}$ zadnjem obdobju kar polovica teh naselij prebivalstvo izgubljala in da je vso povojno obdobje prebivalstvo narašcalo le $\mathbf{v}$ obeh skupinah naselij na Dravskem polju. Podobno kot v predmestnih naseljih, se je prebivalstveni razvoj moæno upočasnil po letu 1981.

\section{SKLEP}

Maribor odseva vse znacilnosti in tudi posebnosti demografskega razvoja mariborske regije in severovzhodne Slovenije $\mathrm{v}$ celoti.Te pa so med drugim tudi zaostajanje za demografskim razvojem Slovenije.Od $25,8 \%$ leta 1981 se je delež prebivalstva severovzhodne Slovenije v republiskem prebivalstvu zmanjßal na $24,9 \%$ leta 1991 . Zaostajal je tudi v oblikovanju strukture prebivalstva urbane družbe , ki je bilo ugotovljeno v strukturni preobrazbi po njegovi Solski izobrazbi, socialni mobilnosti in socialni strukturi. ( V.Klemencix, 1979)

Sklenjeno pozidani teritorij Maribora je v zadnjem desetletju celo izgubil $0,7 \%$ svojega prbivalstva, v predmestnih naseljih se je prebivalstvo pomnožilo za 19 oseb in v obmestnih je nazadovalo za $0,5 \%$. Ker tudi Sirక̌ obmestje ne kaže kaj veð kot stagnacijo, je prebivalstveni razvoj Maribora $\mathbf{v}$ celoti in $\mathbf{v}$ regionalnem pogledu neugoden.Ker se takšne tendence , ki so znacilne za gospodarsko nazadujoča območ ja poglabljajo, so Kusove ugotovitve o kritixni fertilnosti, demografskem staranju in drugih neugodnih razvojnih trendih, povsem na mestu ( Kus , 1989 ).

Podoben prebivalstveni razvoj doživlja samo mesto $v$ celoti in $v$ svoji notranji prebivalstveni zgradbi.V obdobju 1971/81 je prebivalstvo nazadovalo v 23 statistixnih okolisih , v obdobju 
1981/91 pa kar v 42 in v dvajsetletnem obdobju v 34.Sklenjeno obmoxje teh se vedno bolj Siri tudi $\mathrm{v}$ predmestna in obmestna naselja, posebej $\mathrm{v}$ Slovenske gorice. Na ta nacin se $\mathrm{v}$ samem mestu zmanjšje gostota prebivalstva , krepi se le $\mathrm{v}$ nekaterih obrobnih predelih. Mariborsko prebivalstvo, ki se je $\mathrm{v}$ preteklosti razvijalo možno $\mathrm{v}$ povezavi $\mathrm{z}$ delovnimi mesti, takega razvoja ne kaže vec. Ob tem pa se vedno bolj odpira problem socialnogeografske sestave mesta kot elementa celotne mestne zgradbe.

\section{OPOMBE}

1. Obcina Maribor, ki jo Zoran Kus obravnava v svoji publikaciji "Razvoj prebivalstva Maribora na prehodu v 21. stoletje", Maribor 1989, ki je bila 1982 leta razdeljena na 6 občin (Maribor - Pesnica, Pobrežje, Rotovž, Ruse, Tabor in Tezno), ki so bile združene v posebno družbeno-politicno skupnost mesta Maribor. Leta 1990 so bile občine Maribor Pobrežje, Rotovž, Ruše, Tabor in Tezno združene v občino Maribor.

2. Sklenjeno pozidan teritorij Maribora, ki bo $\mathbf{v}$ nadaljnjem obravnavan, je $\mathbf{v}$ mejah statisticnega naselja Maribor in Steje 1991. leta 105431 prebivalcev.

3. Izmed vseh 57 statistixnih kolišev je samo statistǐ̌ni okolix 561730 na skrajnem SZ mesta problematiðen, saj izkazuje v obdobju 1971/81 kar 75.5\% zmanjక̌anje Stevila prebivalstva.

4. Celestina, Dogoše, Kamnica, Košaki, Limbuš, Malečnik, Pekre, Počehova, Razvanje, Ribniško selo, Vinarje, Za Kalvarijo, Zrkovci.

5. Bohova, Brestrnica, Ciglenica, D. Pocehova, Dragučova, Dvorjane, Hrast je, Hrenca, Jalovec, Laznica, Meljski hrib, Metava, Nebova, Pekel, Rogoza, Rošpoh, Sp. Hoč, Sp. Duplek, Trčova, Vodole, Zg. Hoce, Zg. Duplek.

6. V obsegu sedanje občine Maribor.

\section{LITERATURA IN VIRI}

Arh, A., 1990. Socialnogeografska analiza mestnega predela KS Heroja Vojka. Seminarska naloga na PF.Maribor.

Klemencix, V., 1979.Problemi prebivalstva v socialnogeografskem razvoju mariborske regije $\mathbf{v}$ primer javi s celotno Slovenijo. Mariborsko Podravje,s.127-140.Maribor.

Kokole, V., 1985. Medobčinske dnevne migracije v Sloveniji - ob analizi razvojnih možnosti. IB - revija za planiranje st.1,XIX, s.14 - 24.Ljubljana. 
Kus, Z., 1986. Demografski razvoj mariborskih obcin do leta 2000. IB - revija za planiranje st.4-5,XX,s.36-39.Ljubljana.

Kus, Z., 1989.Demografske osnove dolgoročnega prostorskega razvoja Maribora ob prehodu v 21.stolet je.Magistrska naloga.Maribor.

Kus, Z.,1989. Razvoj prebivalstva Maribora na prehodu v 21.stoletje.Maribor.

Oman, M.,1990. Socialnogeografska preobrazba mestnega predela KS Heroja Šercerja. Seminarska naloga na PF.Maribor.

Pak, M.,1967. Socialnogeografska transformacija nekaterih mestnih cetrti Ljubljane in Maribora. Geografski vestnik XXXIX, 1967, s.123-142.Ljubljana.

Pak, M.,1968. Strukturalna in fiziognomska analiza transformacije delov nekaterih mestnih cetrti Maribora. ČZN 4, s.223-235.Maribor.

Pak, M., 1970. Notranja regionalna diferenciacija v mestih Slovenije - na primeru Ljubljane in Maribora.Biro za regionalno prostorsko planiranje 19.Ljubljana.

Pak, M.,1971.Socialnogeografska diferenciacija u gradovima Slovenije.Geographica Slovenica 1, s.147-172.Ljubljana.

Pak, M., 1972. Transformacija vangradskih naselja u gravitacionom podrux̌ ju Maribora. Zbornik na jugoslovanskiot simpozium na problemite na selskite naselbi i zemljodelskoto proizvodstvo,s.159-168.Skopje.

Pak, M., 1974. Geografski elementi socialnega razlikovanja v mestnem prostoru..Geographica Slovenica 3, s.121-131.Ljubljana.

Pak, M., 1979. Prostorski problemi Maribora s posebnim ozirom na industrijsko delovno silo.Mariborsko Podravje, s.53-63.Maribor.

Pak , M., 1980. Industrijska delovna sila v prostorski strukturi Maribora. Geographica Slovenica 10, s.37-53.Ljubljana.

Pak, M., 1987. Nekateri elementi zgradbe in ustroja mestnega središca Maribora. ČZN 58, I. 1987, s.3-20.Maribor.

Pak, M., 1990. Problematika delavskih predelov kot element mestne zgradbe s posebnim ozirom na Maribor.Urejanje prostora 2., s. 20-22.L jubljana.

Pak, M., 1991. Socialnogeografska problematika " delavskih predelov " v zgradbi industrijskih središc, na primeru Maribora. ZN 62, I, 1991, s. 15-24.Maribor.

Popis prebivalstva, gospodinjstev in stanovanj 31.03.1981. Zavod za statistiko SR Slovenije.Ljubljana.

Popis prebivalstva, gospodinjstev, stanovanj in kmeckih gospodarstev v Republiki Sloveniji 31.03.1991. Zavod Republike Slovenije za statistiko.Ljubljana.

Urbanistiðni načrt mesta Maribor 1977.ZUM Maribor. 


\section{SOME EILEMENTS OF POPULATION DEVELOPMENT IN MARIBOR}

Maribor, being a macroregional center of the northeast Slovenia and an old industrial center, have been suffering from stagnation in economy, and consequently, an unfavourable demographic development. Ageing of the population is rapid, its natural increase is under the Slovene average, and the immigration is minimal (appr. 200 persons per year). The total catchment area of Maribor is undergoing a similar demogeographic development.

The study deals with changes in the number of population and hauseholds in the city itself and its inner and outer suburban settlements in the period 1948.91.

While after the World War II, the most rapid growth of population occurred in the very city of Maribor, the population development in later periods was faster in its suburban settlements which have become by now residential areas to the population employed in the city.The most intense increase of population in inner suburban settlements occurred between the years 1961 and 1991 , i.e. by $24,5 \%$ and in the very city of Maribor, by $17,3 \%$.The fastest population growth in the outer suburban settlements occurred in the period 1953-61, i.e. by $13,5 \%$. Such development of population growth was, above all, the result of the following facts:the construction of a big residential settlement in the last fifteen years, re-evaluation of certain areas,mostly working-class districts, which had traditionally been of inferior quality, reconstruction of the old town nucleus, staying of population in rural areas, and rise in the value of rural land, which has stopped the construction of residental buildings on the plains to a great extent. 